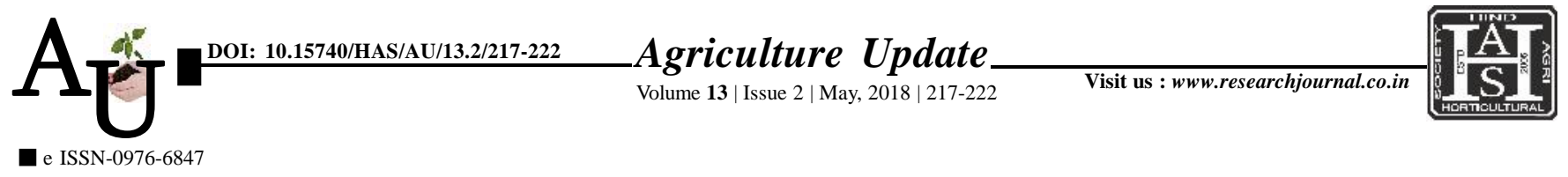

\title{
Research article: Pattern of input services procurement and milk marketing by the dairy farmers from MPCS and other agencies in Dharwad district of Karnataka- an analysis
}

\author{
Priyadarshini C. Gadad and L.B. Kunnal
}

Article Chronicle:

Received :

27.12.2017;

Revised :

07.04.2018;

Accepted :

20.04.2018

KeY Words :

Input services procurement, Milk marketing, MPCS, Other agencies, Sample dairy farmers

Author for correspondence :

Priyadarshini C.

Gadad

Department of

Agricultural Economics,

College of Agriculture,

University of

Agricultural Sciences,

Dharwad (Karnataka)

India

Email:chintipriya@

gmail.com

See end of the article for

authors' affiliations
SUMMARY : The present study was conducted to study the the pattern of inputs procurement by the dairy farmers from milk producers co-operative societies and to analyse the pattern of milk marketing by the members to the milk producers co-operative societies.Multistage sampling procedure was followed for selection of 120 sample Dairy farmers. The data pertained to the agricultural year 2014-15. Tabular analysis was used to analyze the data. The input supply services like feed, fodder, veterinary services, loan facilities and milk cans were analysed in terms average quantity of procurement and frequency of procurement. The average quantity of feed purchased by a member from the society was $485 \mathrm{~kg}$ per annum, the average quantity of fodder purchased by a member was four quintals per annum. The society could extend veterinary services to the needy 25 members. The loan facilities of the MPCS were availed by 24 members. The number of dairy farmers opting to purchase inputs from other agencies other than MPCS was less. As per the opinion of members of societies, it was observed that the performance of the society was better. The members in the study area were highly satisfied regarding the supply of inputs (76.67\%). Training to members and accessibility to market news to the members were poor in the whole study area. The pattern of sale of fluid milk by the sample dairy farmers to the different agencies showed that all the 120 sample farmers sold the milk to the dairy co-operative society. Apart from selling to MPCS, 26 sample farmers sold milk to the local consumers and six members to the sweet shops and hotels. Thus, the results of the study brings to focus that, the concerned agencies, development departments and others should focus more on sample dairy farmers by providing required facilities and other necessary help in effective running of dairy farming.

How to cite this article : Gadad, Priyadarshini C. and Kunnal, L.B. (2018). Pattern of input services procurement and milk marketing by the dairy farmers from MPCS and other agencies in Dharwad district of Karnataka- an analysis. Agric. Update, 13(2): 217-222; DOI : 10.15740/HAS/AU/13.2/217-222. Copyright@ 2018: Hind AgriHorticultural Society. 